Article

\title{
Distributing Leadership or Distributing Tasks? The Practice of Distributed Leadership by Management and Its Limitations in Two Spanish Secondary Schools
}

\author{
Inmaculada Gómez-Hurtado, Inmaculada González-Falcón *, Jose M. Coronel-Llamas and \\ María del Pilar García-Rodríguez \\ Department of Pedagogy, Faculty of Education, Psychology and Sports Sciences, University of Huelva, \\ 21071 Huelva, Spain; Inmaculada.gomez@dedu.uhu.es (I.G.-H.); coronel@dedu.uhu.es (J.M.C.-L.); \\ mjcarra@dedu.uhu.es (M.d.P.G.-R.) \\ * Correspondence: inmaculada.gonzalez@dedu.uhu.es
}

Received: 30 March 2020; Accepted: 21 April 2020; Published: 25 April 2020

\begin{abstract}
The need to explore new forms of leadership in schools, among other available alternatives, leads to the reflection upon the way in which—specifically from the principal's office-it is developed, implemented and distributed. This paper presents two case studies in Spanish secondary schools in which the practices are analyzed and the limitations recognized in the exercise of distributed leadership by their principals. This study used interviews and shadowing of the principals, recording the observations of meetings and interviews with other influential agents from each school. Despite the particular differences in each case and a greater role of social interaction processes, the outcomes reflect the persistent focus on the individual action of the principals and the pre-eminence of formal and bureaucratic components in the development of distributed leadership. This situation prevents progress beyond the mere distribution of management tasks and hinders the possibilities of consolidating other forms of leadership expression that involve more agents and groups.
\end{abstract}

Keywords: distributed leadership; school principalship; school management; bureaucratic leadership; Secondary Education

\section{Introduction}

This aim of this work is to contribute to the way in which distributed leadership (henceforth, DL), takes on significance in the life of public schools; specifically, by examining the practice of DL implemented by the school principals. The decision to focus on the figure of the principal is justified by the evolution of the concept of leadership per se and its development in organizations. The literature helps explain the situation better.

The terms management and leadership are used indistinctly, so that most research does not suitably distinguish what is day-to-day practice (management) and what is found in organizations as a distinct qualitative process (leadership). Thus, the existence of leadership as an observable aspect in the daily life of organizations has been questioned, so there are difficulties in identifying it easily in organizational practice [1,2].

Leadership has become highly relevant over time in all social spheres, including education [3], mainly responding to what might be called a bureaucratic leadership and management model. Leadership has been conceptualized from a primarily individualistic perspective [4], as a result of using the terms management and leadership indistinctly and turning management into a task essentially carried out by the executive.

In this way, the focus on individual actions emphasizes psychological aspects, neglects context and simplifies reality by failing to consider social dynamics [5]. 
However, the evolution of the studies leads to the recognition of contributions from critical and post-structural approaches [3,6-8]. Among other aspects, the roles of collaboration and sharing as elements of the nature of leadership are acknowledged, leaving aside the most individualistic perspective [9]. In addition, the importance of the organizational context and other agents is valued; the interaction appears as a key piece paying attention to dimensions of a more symbolic and social nature. This way, the works approach a more collective and community perspective, when considering leadership as a socially constructed process and in a more collective way $[10,11]$.

In relation to this debate that emerges in the literature, the objective of the present work is precisely to analyze the DL practices carried out by the management in two secondary schools and assess the extent to which they are positioned beyond the distribution of management tasks and formal positions, giving space to other members of the school and ways of expressing leadership.

\subsection{Distributed Leadership, Management and Direction in Public Service Education Organizations}

The concept of DL has gradually acquired an important role in the academic sphere in general and, specifically in the educational context [12-16], particularly in those organizations with team-based organizational structures $[15,17,18]$.

The distributed perspective offers a framework for analysis of educational leadership [19-27]. Authors such as Gronn and Spillane highlighted the term, given their insistence on placing the focus on the organizational versus the individual, and on interactions versus actions. Leading schools efficiently call for the involvement of different leaders in formal and informal positions that assume responsibilities in the organization [28-30]. However, it is not just about merely distributing tasks or increasing collaboration [31,32]; the authors are simply talking about the issues concerning power and its use by members of the school $[33,34]$.

Given the acknowledgment of the role of school management, the literature has taken care to reflect the way in which principals develop DL in their schools [35-37]. These distributed leadership practices may include different modalities, from autocratic to democratic $[16,27,38]$. In the literature, it is emphasized that delegation and devolution should not be confused with distributed leadership simply because they involve top-down influence rather than bottom-up. Nevertheless, the decisions taken by formal committees are considered as formulas in which leadership is shared and whereby a very significant influence is exerted on the organization [39-42]. Along this line, in works such as those by Spillane et al., the teaching teams, structured in formal groupings, are examples of DL, and their interactions evidence of "the constitution of DL".

Particularly in secondary schools, works such as those by [43-47], acknowledge the need for leadership to be exercised both by the management and by other members of the educational community. In this sense, the proposals on collective leadership [48-51] represent an effort to go beyond the formal leadership exercised by school management. Therefore, advancing in the analysis of the DL processes driven by school management may be of interest and could contribute to the study of more participatory and democratic formulas [52] in the leadership of educational organizations.

\subsection{Current State of School Management in Spanish Schools.}

According to [53], with the arrival of the law regulating education in Spain in 1985, the development of the educational policies in our country was associated with putting organizational structures into practice that could allow for the participation in the management of schools. The idea was to seek the participation of all the social agents involved in education (parents, teachers, pupils, and others), taking autonomy and decentralization as references.

The distribution of leadership in Spain is mainly based on the formal component. Primary and secondary schools have both the principal as formal leader and other educational agents that can also exercise leadership. This is reflected in the organs of governance.

Spanish principals are not career professionals, but rather are elected from-and also partly by - the teaching staff of each school, and by the representatives of the educational administration. 
Their mandate lasts for four years, and can be made compatible with teaching activity. To become a principal, it is necessary to meet certain administrative requirements, undergo specific training and submit a management project. The reality is that it is hard to find candidates for the post.

It must be taken into account that in Spain, under a policy of state interventionism, schools have developed schemes of democratic participation in management assuming approaches of a bureaucratic leadership model. In addition, the changes and educational reforms reflected-above all and excessively - at the legislative level have identified school leadership as the main actor in this task. This way, the principal's position of power in the hierarchical organization of the school holds sway. Their privileged situation, with respect to the mechanisms of organizational influence and control, has made them the subject of scrutiny. The aim was to show that it is the principal who marks the difference and that putting certain skills for effective management into practice ensures the success of the school as a whole.

This situation, in principle conducive to the development of distributed leadership by the management, often runs the risk of being limited to formal and bureaucratic aspects, far removed from genuine participation and the involvement of other agents and members of the school. Principals, aware of their power in the school's organizational structure and as representatives of the educational authority, take the regulations as a basis for action, giving priority to formal and bureaucratic components. It is noteworthy to bear in mind that Spanish educational institutions are considered as having a lesser degree of autonomy compared to others in the European environment [54]. It is in this context that the authors propose this study, analyzing the practices and limitations of the distributed leadership of two secondary school principals.

\section{Materials and Methods}

\subsection{Methods}

This study is part of broader research into distributed leadership. (Research Project -EDU2011-26436-: Distributed leadership in schools: Scope and modalities). The investigation was carried out in two phases: the first enabled us to identify the key agents of each school (thanks to the application of Daily Practice of Leadership, [55]; and the Questionnaire on the School SocialNetwork, REDSODE), based on the analysis of social networks [56]. In the second phase, the subject of this article, this study investigated the configuration and practices of the leadership exercised by management and the limitations of distributed leadership. In this second phase, the researchers carried out 10 case studies adopting a qualitative approach [57] and applying case study methodology [58,59]. Herein two state-run Spanish secondary school cases are presented. The schools were chosen because they present diversity in their composition and size, context, faculty and pupils. They also differ in their institutional trajectories and organizational cultures.

\subsection{Context}

Case 1 corresponds to a Secondary, Baccalaureate and Vocational Education (hereinafter VE) center located in the city of Huelva. It is a large institution, with seven buildings on three hectares of land, and approximately 900 students and between 80 and 90 teachers. It has always been one of the benchmark centers in the VE area. Its socio-economic and cultural context is medium-low, with a great diversity and presence of immigrant students and other pupils with special educational needs. Family participation is low and in the minority. Throughout its 80-year trajectory, different management teams have held sway, most of them, linked to VE. The current principal is finalizing her second mandate and continues to maintain the good relationships of the center with its surroundings and context. A large number of projects are carried out, many of them aimed at reducing student discipline problems and improving poor academic results.

Case 2 makes reference to a publicly-owned Education Center located in a town in the province of Huelva, exclusively for secondary education. The school has an educational reinforcement program 
for low-performing pupils. The faculty consists of thirty teachers, with 400 students, of which $16 \%$ are immigrants. The families have a medium-low socio-cultural level but show great concern for their children's education. As for the pupil profile, the coexistence in the classroom of responsible and highly motivated students for the study is perceived, despite the existence of a clear academic deficit, mainly accumulated in the instrumental areas of language and math. In general, the academic outcomes are low. The school was founded 20 years ago and had two principals prior to the current head. The school culture is closely linked with the locality. The relationships with the environment are also very positive.

\subsection{Procedure Data Collection}

The data were gathered using interviews, shadowing sessions and records of observations of meetings. Interviews and observations were audio recorded. Applying the three instruments, researchers used a field notebook with a common structure to collect data (one type for each as outlined below). The data collection consisted of: Three in-depth interviews with each principal, and three/four with other agents considered key leadership components (teachers who were part of the formal management teams, that is, department heads, the teaching coordination team, and teachers who play an important role as non-formal leaders; in both cases, they were identified as key agents in the first phase of this research) (n: 12 interviews). Shadowing sessions [60] were also held, where the daily activities of the principal and agents with whom they interacted were recorded (more than thirty different activities were logged in each school; approximately 60 activities) during twelve working days over a three-month period (two per month/each center). The records of observations of the meetings of different teams and agents were also kept (management team sessions, meetings, department heads liaising with agents from outside the school, that is, parents and people responsible for the training organizations of the administration), as well as various informal conversations in the days spent in the schools (8 meetings).

The interviews were designed by the research team and the contents were structured focusing on four main aspects: history, evolution and main characteristic of the school; the role of the principal and other sources of power; leadership practices and interactions; difficulties in complying principal's projects and school vision.

The shadowing sessions followed an observation schema in which data were collected on the situation, including the type of activity carried out; the agents involved; the content and purpose of the meeting; the principal's role in the action and the others involved; the location and spatial distribution of the participants; the social climate during the activity; the date, time of day and approximate duration of the session or meeting.

In the observations of the formal meetings, the intervening agents, their speeches and contents of the same, and the interventions and interactions between them were recorded, drawing up a map of relationships after the meeting.

\subsection{Analysis}

For the content analysis used in this study, a deductive category approach was applied [61]. In the interviews, there were shadowing sessions and records of observations of meetings. The research team responsible for carrying out the analyses and triangulating the information drew up and agreed upon a system of categories that was analyzed using MAXQDA software (version 10). The system of categories and codes was applied to all the data collection (interviews, observation records, shadowing schedules and researchers' notes). The distributed leadership practices implemented by the principals and their limitations were established based on the following categories of analysis: School context and features; school history (principal succession, meaningful school agents); decision-making processes and interactions; patterns of influence (autocratic, bureaucratic, technocratic, ideological or micro-political) and external and internal sources of power; agents involved and major leaders of the center; relationship flows; communication and coordination channels and devices used in these 
dynamics; principal availability and accessibility; participation of the educational community in the definition of school projects and initiatives; flexibility—openness to change—of these proposals; and difficulties in the development of interactions. All these categories are present in the previous literature as elements which condition the leadership exercised in schools. This study, as [62] recommends, moved from one understanding to another, trying to write a report that helps others understand how things works and what is happening in these cases. Once the data were obtained, and after a preliminary analysis verified by the research team and by each center, an investigation report was prepared for each case. In this paper, this study presents the results associated with the practice of DL exercised by the principal's office, as well as the limitations found in its development. The value of this study lies in the presentation of the cases which reflect the weaknesses and possibilities of the distributed leadership exercised by the principals and how leadership is evolving.

\section{Results}

\subsection{Practice of Distributed Leadership by Principals}

\subsubsection{Case 1}

The principal of the education center is very clear about her management project and the way in which she wants to exercise her leadership. Her main objectives are to expand the secondary education training offer and improve coexistence in the school. Her own idea of leadership reflects an entrepreneurial vision, opting for a management that organizes, supervises and decides the course to follow but also for a committee in which to delegate and confide. She considers it crucial to have a good working team. However, her presence and personal role is indisputable when explaining how the center operates: "I am the daughter of small business people. So, I'm well versed in business affairs, in creating, in doing... And they tell me I'm a bossy-boots ... " (Principal).

Despite this, the principal has no choice but to rely especially on her vice principal and secretary, as well as on the members of the teaching coordination team. She tries to ensure that this team has initiative and autonomy in decision making and that there is fluid communication with the rest of the center. In spite of this, the authors observed that the principal controls practically all the matters and management issues with weekly meetings of the management team and also, although it is not obligatory, of the teaching coordination team (Shadowing).

Initially, the principal's DL practices aim to move away from a bureaucratic style. Sometimes, she uses the regulations to define the projects to be carried out or as a resource for decision making. Likewise, she employs her own rules, which she uses to define the functions of each formal leader, even if it does not match what is set out in the law. For example, in relation to administrative and service personnel, the principal instructs them: "Let's see, these are the operational rules, what you think of them? Can you contribute something? Well, what you have to do, it is this, that and this ... That is your function. The teacher on call has these, the team has this... but try to ensure that everything forms a chain and that each link fulfills its function." (Principal).

At other times, the principal prefers to appeal to each person's competencies, abilities and skills. These types of appeals are incorporated—albeit with several difficulties-into a discourse focused on the vision of the center, aims and objectives, which she has defined: "I'm going to set up what is best for the center. We must prioritize it... whether we agree or not; that doesn't matter!" (Principal). Occasionally, she does not avoid confrontation, in order to maintain coherence with herself and her project, so much so, that on occasion, defending it has meant positioning herself against her teammates and her own management team.

To speed up the work and avoid the frustration of teachers faced with the large number of bureaucratic tasks, she undertakes a good part of them herself (Shadowing). In critical situations, the principal does not hesitate to involve all teachers in decision making, but also ensures that she has sufficient support to reinforce the unity of the management team and the teacher coordination team and secure the influence of both bodies before the voting takes place. In this sense, the secretary noted: 
"I have always been totally loyal when working with her. We discuss everything we have to discuss, but apart from that, whatever the management team says to me, even if I might be against it, is the word of God." (Secretary).

The principal distributes the leadership among other members of the team responsible for management. They include the secretary, the vice principal and the head of studies, all of them pertaining to secondary education and Baccalaureate, leaving aside the Vocational Training faculty. In all three cases, their competencies as professionals are highly valued, also recognizing in the first two cases the knowledge they have "of all the ins and outs of the center", for the extensive experience they have accumulated in different management teams and their seniority in the same. All three agree on pointing out the importance of managing beyond the norm. For them, it is essential to know why things are done and justify them based on a well-defined project. Regarding the head of studies, the principal also highlights her ability to coordinate and influence different people: "I wanted to incorporate all the members, so called meetings with non-teaching staff. We did a survey to collect contributions to help improve the day-to-day running of the center, problems such as discipline, coming late to class, cleanliness." (Head of Studies). An attempt to overcome the bureaucratic procedures to provide input for the participation of other members in school decision-making seems apparent from this statement, but the success of these initiatives is not clear.

On the other hand, two clearly differentiated professional cultures can be observed in this center [63]. One is evidenced in the secondary and high school teachers, and the other brings together the VE teachers. Historically, the latter have usually had greater weight, but with the entry in recent years of secondary and Baccalaureate programs, the coexistence and organizational culture underwent changes. The principal tries to develop distributed and democratic leadership. However, she mainly relies on the formal leaders belonging to the management team and the teacher coordination team. The majority of their members (all but one) represent only the secondary and Baccalaureate teachers. In this sense, the center's VE faculty feel under-acknowledged and call for more attention, communication and interest toward these teaching areas from the principal. These teachers are unhappy with the current direction taken by the center, as they perceive that their VE teachings and their work as professionals, in their opinion, are not accorded the acknowledgment they deserve. There is a palpable feeling of "identity loss" and discomfort due to the existence of a climate in the center that does not recognize them. These teachers have lost the power and ability to influence the life of the center, and it is precisely part of this group that is currently offering some resistance to management policies implemented from the principal's office.

\subsubsection{Case 2}

The principal of this school also takes the regulations as the basis for her management policy and relies on the rest of the management team for its development. This circumstance leads significant members of the school, such as the former principal, to consider that: "I see a principalship that runs the school properly, is carrying out its function based on the regulations, but in the rest I do not see a pedagogical leader who is taking the projects forward." (Former principal).

The school principal assumes the role of a formal leader based on the unipersonal bodies (secretary and head of studies) and collegiate bodies (teaching faculty, school board and teaching teams), as specified by law. The members interviewed in the study emphasize the importance of compliance with the regulations in the school, with the management team taking responsibility for it: "The way to lead is by following the regulations across the board. Here there is neither humanity nor sentiment. Here there are rules." (Therapeutic Pedagogy Teacher).

The principal uses her hierarchical position in the organization and concentrates the practice of DL in the management team. "Here, there are no adjacent leaders for better or worse. There could be a positive leader not officially being from the management team, but there isn't one." (Former principal). Team functions and tasks are distributed among its three members, attempting to remain faithful to those set forth in the regulations. They also share tasks equally and underline the importance of 
coordination and knowledge of everything that goes on in the organization: "There are some things that we split up between us. For example, I handle the issue of teacher absences or analyzing assessments, but then there are things that... Like matters of coexistence and behavioral reports, are managed by the head of studies, and the economic secretary does the financial side. But later there are many things to share. We hold a meeting once a week and in all the informal discussion there are always a lot of things that we do together, because otherwise it would be impossible and this way, we keep abreast of everything. We do everything possible so that no one is indispensable, in case one day one of them is absent for some reason, so that the rest can keep working." (Principal).

\subsection{Limitations of DLExercised by Management}

\subsubsection{Case 1}

Regarding the limitations of case 1, the principal's efforts to improve the climate of the center are acknowledged and, in general, she is considered a competent leader. However, the truth is that her tendency to want to be informed and participate in different issues are also perceived as intrusion and control. In this sense, her maxim that the different formal leaders have initiative and can make their decisions without consulting her translates in practice into greater levels of freedom so that she herself can make decisions without sharing them with the rest of her team. Further, there is some regret concerning the lack of a different attitude: "You have to talk and interact much more to get to know everything and everyone" (Deputy Head of Studies, Compulsory Secondary Education (ESO) and Baccalaureate). "It would do her good to leave her office more often and come downstairs." (Shadowing). In addition, it was observed that the only measure to introduce the VE training teachers to the central leadership was the inclusion in a formal position of the management team.

Actually, what underlies all this is the lack of a true center project in common. The principal has her "own project" and therefore clashes with the rest of the VE teachers and members of her own management team (the secretary, for example), who also have their own or do not fully share her vision. The fact is that the principal has not been able to persuade teaching staff or involve the rest of the educational community. Along this line of thought, it is essential that there is a focus toward the participation of families and students in general. The observations and conversations held confirm that the student body is the great absentee: They formally participate in school councils and as class delegates/representatives, but are not included in the "creation and construction processes" of their school. Similarly, family-school relationships are scarce and participation is low, despite the fact that the faculty and the management team acknowledge their important role.

On the other hand, the large size of the center, with differentiated spaces and buildings for teachers of different subjects, or the large amount of bureaucratic work, could be reasons to decentralize and better distribute leadership practice. However, in this case, they become an aggravating factor for its development. Thus, in terms of bureaucratic tasks, this study found that the principal assumes most of them, with the intention of freeing "the faculty from this burden", a fact positively valued by this group. This decision — which can lead to exhaustion—is an obvious sign of the limitations observed in the practice of DL by the principal.

Thus, the results acknowledge that in order to advance in the development of a more distributed leadership in this center, work should be done on the limitations identified: a) Involving the whole faculty and educational community in the definition and vision of the center; $b$ ) ensuring that decision making is not so centralized in formal leaders, even if tasks and responsibilities are distributed, involving all teachers; c) working with families to develop different activities to get them more involved; d) developing campaigns to promote student participation in school decision making.

\subsubsection{Case 2}

In this case, the focus is on a school that distributes tasks among the management team. There is no distribution of leadership among the different members of the educational community due to their 
competencies or other characteristics. The tasks are only distributed as stipulated by the regulations, and this mainly affects the formal bodies. Rather than leadership, the focus could be about management.

The principal is seen as very thorough and controlling. She is credited with great concern for pupils and their families. "The principal does everything perfectly, to the millimeter, in her style ... she controls everything, and she does it the way she has to ... she knows the families, but if the child needs to be expelled, she will do it." (Clerical staff).

The principal's management project is based on two strengths: performance improvement and coexistence in the school. She considers the family a key agent in the running of the school and tries to encourage initiatives to increase their participation. For the head of studies, one of the priority lines related to his functions is linked to coexistence in the school and the secretary is dedicated to the school's economic and administrative affairs. In practice, the principal carries out DL focused on the management team as the driving force of the school, which means she gives great importance to coordination of the team. This is characterized by the informative meetings held by the three members of the management team-or at least two of them-to coordinate their practices and work as a team rather than in isolation (Shadowing).

On the other hand, the principal feels that there is a lack of involvement of the rest of the teachers in the school. However, she feels supported by the former principal and the school counselor, whom she uses as intermediate leaders, leveraging them as a means to bring teachers closer to her management project.

In this school, formal leadership is mostly left to the management team. Formal and bureaucratic mechanisms prevail over other aspects in the configuration of school policies. However, the principal states that she would like more support from the educational community in order to implement a more collegial approach to management. Although it is the management team which, through the regulations, becomes the cornerstone for the exercise of power in the school, there are other people who are of great relevance for the study of relationships in it. These people should have a voice, and value and consider them as an opportunity to move forward in the democratic life of the school and in collective leadership. This comment from a teacher reaffirms the importance and influence of other members of the school and the need to incorporate them into the decision-making process: "I don't think there is a management team as rigid as this in the world; and I'll tell you one thing. From last year, when the other counselor was here, to this year, with a new counselor in place, this has changed as though from night to day. It's hard to imagine." (Teacher). This person exerts a degree of influence on the management team, making them less rigid in their decisions. The counselor has become the management team's "confessor", and they often follow the guidance she gives them in the events that occur. Her role in the school and the work she does in it are highlighted. The arguments she uses are based on the commitment to a more cohesive academic faculty and school board.

Similarly, the former principal of the school—currently performing teaching duties_also has an important influence. Not only has he left his mark on the school identity, but he also remains one of the main faculty spokespersons. Colleagues value him as one of the most significant characters and acknowledge that his support for the current management team in school decision making is essential. His arguments are based on aspects related to the school culture and identity. It should be noted that he is one of the influential leaders in the school and is supported, at the same time, by the teaching staff but also considered by the management team.

As a result of DL practice rigorously focused on formal components, it is necessary to underline the existence of a group of teachers who try to oppose the management team. These teachers try to formulate arguments against the management team's proposals through persuasion in informal meetings held either inside or outside the school (Shadowing). This group of teachers tries to persuade the rest of their colleagues based on the interpretation of different data according to their criteria. This has caused malaise between the management team and the rest of the teaching staff and vice versa, creating a certain distance, and tension, at some points in the faculty and school board meetings. 
In this case, the main limitations identified come from a practice of DL focused on the management team members that act as guarantors of the regulations. Although the tasks are distributed among the management team members, it is they who exert the greatest influence on the running of the organization and make the regulations the basis of the practices carried out in the school. Thus, some faculty members perceive the management team as a less human and comprehensive team, as their practice is based on the importance of the norm without taking into account the personal circumstances of each member. It is also true that the principal feels, like other members of the school, that there is a lack of faculty involvement in the drafting of proposals, for example, those that have a direct impact on students. Thus, both aspects (lack of involvement of teachers and management style that is not very human and highly bureaucratic) act as important barriers to the distribution of leadership.

\section{Discussion}

Various questions emerge from the results of this work: Is the management of these centers in suitable conditions to work on the development of a DL that goes beyond the formal distribution of tasks? Are we talking about distributed leadership or distributed management? Is it a formal or social distribution of leadership?

The analysis of the distributed leadership practices seems to indicate that the principals use the formal structure of the school and the regulations available as elements upon which to base their work in school. This role given to these components allows them to carry out their work with a greater or lesser degree of success. However, this is a job closer to management than to leadership because, despite being distributed, the practices analyzed are more in line with the formal than the social. The presence of other members from outside the school management and coordination structure is not significant. Informal and social aspects are buried under bureaucratic requirements and by a work style incapable of welcoming other voices, actors and approaches to decision making. This causes resentment, undermining involvement and commitment, and helps explain the futility of some of the principal's efforts to incorporate other members of the school into projects and initiatives.

In this sense, although the principals continue to be the drivers of the organizational dynamics around which the exercise of leadership pivots, the rest of the organization's members (teachers, families, educational agents) must have the conditions that facilitate availability for the development of interactions, constructive dialog and mutual learning at the individual and organizational level. Paying attention to these practices has made it possible to acknowledge the possibilities and limits of DL and the convergence of objectives, but also the situations of conflict and discrepancy [10].

The actions of the principals in the configuration and distribution of the leadership observed in these centers are key. With a greater or lesser degree of success, the authors found different distributed leadership patterns or structures. On the one hand, they inspire and provide enough influence to formal leaders and members of the teaching teams and, on the other, the control exercised in the different tasks and issues limits the development of more participatory, democratic and distributed structures.

Along with the management teams, this study identified other members of the school participating in the exercise of leadership $[29,64-66]$ This extension of leadership is identified in the literature [42,67-71] as one of the key factors when it comes to creating and promoting a professional learning community. However, it is true that dysfunctions also occur in distribution. On the one hand, not all the school staff participate in the same way. In fact, some of the interviewees' testimonies claim that there is a lack of communication fluency and the same opportunities to participate are not provided. [71]. These comments logically come from teachers in opposition to the management, and may be due to personal matters, or simply other factors derived from the type of school [72,73]. However, they also refer to the inclusion of families and students in the organizational formulas [74]. In both cases, they are afforded fewer opportunities for real participation.

This study has also verified that not all principals are able to combine educational objectives with relational elements in a balanced way $[75,76]$. As for the formulas in which responsibilities are distributed, this study found in both cases: (a) a division of work both among teams and specific 
people; different leaders perform different tasks separately; (b) a co-leadership in collaboration, as many of the tasks defined by regulations in the management figure are distributed among the members of the management team, so the delimitation of who is who becomes blurred. In these cases, they share and exchange functions according to their personal abilities; and (c) a leadership in parallel that is evident in the testimonies expressed by other managers.

It is difficult to answer how efficient and productive forms of distribution can be developed, or what the best interventions are to achieve it. At any given time and depending on the contexts and needs, as already explained, the principals make decisions that are sometimes right and others that are not. Works like those of [8]., for example, acknowledge the way in which principals are able to identify potential leaders, create opportunities for them, and facilitate and provide support for their expression. In the centers analyzed in this work, the school structures and routines did not particularly contribute to the expression of a different kind of leadership. The division of work between managers (management team) and workers (teachers) is manifest and evident. The presence of opportunities within a bureaucratic culture to move toward a more inclusive and democratic alternative [77] does not seem to be verified.

Society cannot remain satisfied with the milestones achieved. The distribution of leadership is just one small step on the road to collective leadership and organizational democracy [76,78,79]. In this sense, [80] is critical of the equation of distributed leadership with organizational democracy. Similarly, [81] are wary of this discourse of distributed leadership, as an "anti-democratic managerial bias" remains within its premise. To some extent, the permanence of rigid structures and organizational cultures barely permeable to changes and variations in the status quo that help maintain management control of the organization cannot be ignored, notwithstanding all the efforts to distribute or share the work and activities. The challenge of moving from distributed leadership to collective leadership must be supported by educational policies that promote democracy, autonomy and educational participation; by more and better organizational arrangements and resources that encourage their development; and by a restructuring of the work and activities carried out in schools by the different groups involved. In short, there is a need for a rethinking of the meaning and functions of school institutions in contemporary societies. Finally, in the commitment to democratize educational organizations, DL is likely to be just one more step on the road to collective leadership. The commitment to democratizing and enriching schools [80], not forgetting the importance and work required to design the necessary conditions for its implementation, calls for a move toward collective leadership and organizational democracy.

\section{Conclusions}

Distributed leadership is a common exercise in both schools although there is a long road still left to travel. Leadership is shaped by contextual characteristics, the principals' backgrounds, a low level of autonomy, the principal's versus staff's projects and vision, relations and interactions. As Paredes-Scribner [18] stated, leadership is a highly complex social process that manifests itself in many contexts and in many different ways. Our cases are examples of this fact, because our schools combine distributed leadership, social distribution, and sometimes distributed management, formal distribution. Therefore, both schools should promote bottom-up more than top-down influence.

Leadership is evolving towards new approaches. Society is moving from individual leaderships' approaches to others of a more distributed nature, with all their pros and cons. In our findings, there are many such attempts underway, partly because administrations and scientists are committed to the DL approach and partly because leaders are striving to further this trend.

Reflecting beyond distribution, the school is an organization that can meet the conditions for the expression of collective leadership, but the question is whether the management is in suitable conditions to work in this direction. Collective leadership is not incorporated in our western culture and this type of proposal is frightening [51]. It involves moving beyond the mere distribution of responsibilities and developing the notion of interaction and its nature and meaning in greater depth. 
In this sense, the results of this study show that despite continuing to be the protagonists of the organizational dynamics and the focus around which the exercise of leadership hinges, the rest of the members of the organization (teachers, families, educational agents, stakeholders) need to have conditions that facilitate availability for the development of interactions and constructive dialogue, for the exchange of points of view, and responsibility and mutual learning at the individual and organizational level. Furthermore, a different approach to the use of power as a constituent and regulating mechanism of social relations is required. Likewise, as recommended by [77], what is needed is a more multidirectional and multidimensional use of power, promoting the development of communities based on collective values and actions, building informal networks, fostering cohesion and links among members, and encouraging others to share resources.

The limitations identified can serve as clues to take the development of a more inclusive and democratic distributed leadership forward. In each school and depending on their contextual features, the principles as figureheads and their team should "relax" somewhat, distancing themselves slightly further from the bureaucratic and formal, and show confidence in the actions and decision taken by school members, sharing their objectives, school mission and vision. The joint involvement of faculty, family and students in defining the school is fundamental.

In our cases, staff, students and families, do not share the same mission and vision of their schools, and this fact should be modified. Educational agents (teachers, students, families, administration, politicians, external organizations and society in general) must reflect together on the concept of governance and leadership, while articulating more flexible structures for real collaboration among them all. In this scenario, it is essential that the centers are able to rid themselves of controlling policies and bureaucratic straitjackets, bearing in mind that the Spanish education system is one of the least autonomous in the international context. Principals find themselves caught up in the bureaucratic machinery, which hinders the articulation of more open, democratic and egalitarian management structures that allow more time for discussion. Therefore, a new collaborative culture must be redefined, in which no member of the educational community feels neglected. Care should also be taken to nurture informal relationships, listening more and strengthening the inclusion of teachers and families and students. If collectively led democratic organizations are wanted, it is also crucial to set an example and that the students learn along with us, and we from them.

Further, nor can the authors fail to mention the limitations of a study like this, in which the focus has been on the principals. The research hinged around them. Perhaps this focus may run the risk of marginalizing and leaving in the background a more detailed and thorough analysis of the behavior, actions and practices of other members of the school and their role in this process. To this end, it seems appropriate to carry out research that focuses on social interactions, on the role of other agents and on relational aspects in order to better understand the expression of leadership in schools.

The practices and limitations identified in this work highlight the need to move toward to a more collective and democratic leadership. Collective leadership seeks the creation of new forms of participation in democratic learning communities, surpassing both the liberal democratic models and their formal mechanisms. It is here that collective leadership emerges as support for the creation of contexts to bring participation to the "marginalized" and traditionally silenced voices, working to achieve a distribution of power among all educational agents, with schools that pay due attention to all their members. Democracy is more than a system of participation in management. Democracy is related to issues of equality and justice and affects all levels of social and institutional life. The role of the school in the construction of a democracy must be recovered in order to ensure the social and cultural commitment assigned to it as an educational institution.

In future works, the authors intend to focus more attention on a few aspects: Our research coincides with others focused on DL that start from formal leadership positions $[40,82,83]$. The focus of our studies continues to be the principals. In our case, this trend is the result of our context, although it should not be forgotten that this may have conditioned us when recognizing and tracking informal leaders and their contributions. Therefore, the authors believe that there should be reinforcement of 
this trend in future. Secondly, the authors would like to see the consequences of the fact that this leadership model is being driven by administrations from outside school organizations, as pointed out by [84], and is not a core need demanded by them. Thirdly, it would be interesting to incorporate, likewise, variables such as gender and their possible influence on the practice of leadership, as well as an in-depth study of the implications of the status of asymmetries between formal and non-formal leaders. [37,73].

The cases analyzed in this paper are an example of the difficulty of moving in this direction and highlights the need to continue researching cases that reflect what is happening in our schools in their way to changing and improving their realities.

Author Contributions: All authors have contributed to all the steps of this research (design, field-work, analyze) and to the elaboration of this paper. Conceptualization, I.G.-H., I.G.-F., J.M.C.-L. and M.d.P.G.-R.; Data curation, J.M.C.-L. and M.d.P.G.-R.; Formal analysis, I.G.-H., I.G.-F., J.M.C.-L. and M.d.P.G.-R.; Investigation, I.G.-H., I.G.-F., J.M.C.-L. and M.d.P.G.-R.; Methodology, I.G.-H., I.G.-F., J.M.C.-L. and M.d.P.G.-R.; Resources, J.M.C.-L.; Supervision, I.G.-F. and J.M.C.-L.; Writing-original draft, I.G.-H., I.G.-F., J.M.C.-L. and M.d.P.G.-R.; Writing-review \& editing, I.G.-H., I.G.-F., J.M.C.-L. and M.d.P.G.-R. All authors have read and agreed to the published version of the manuscript.

Funding: This work is framed within the R+D+I project: "Leadership distribution in schools. Scope and modalities" (EDU 2011-26436), subsidized by the Spanish Ministry of Science and Innovation. Coord: Julián López Yáñez.

Conflicts of Interest: The authors declare no conflict of interest.

\section{References}

1. Alvesson, M.; Sveningsson, S. The great disappearance act: Difficulties in doing leadership. Leadersh. $Q$. 2003, 14, 359-381. [CrossRef]

2. Alvesson, M.; Sveningsson, S. Managers doing leadership: The extra ordinarization of the mundane. Hum. Relat. 2003, 56, 1435-1459. [CrossRef]

3. Alvesson, M.; Spicer, A. Theories of leadership. In Metaphors We Lead by: Understanding Leadership in the Real World; Alvesson, M., Spicer, A., Eds.; Routledge: London, UK, 2011; pp. 31-50.

4. Wilson, Z. Situated knowledge: A Foucauldian reading of ancient and modern classics of leadership thought. Leadership 2013, 9, 43-61. [CrossRef]

5. Alvesson, M.; Kärreman, D. Intellectual failure and ideological success in organization studies: The case of transformational leadership. J. Manag. Inq. 2016, 25, 139-152. [CrossRef]

6. Davies, P.M.; Popescu, A.C.; Gunter, H.M. Critical approaches to education policy and leadership. Manag. Educ. 2011, 25, 47-49. [CrossRef]

7. Jackson, B.; Parry, K. A Very Short, Fairly Interesting and Reasonably Cheap Studying Leadership, 2nd ed.; Sage: London, UK, 2011; ISBN 1849207380.

8. Klar, H.W.; Shawn, K.; Hammonds, H.L.; Buskey, F.C. Fostering the capacity for distributed leadership: A post-heroic approach to leading school improvement. Int. J. Leadersh. Educ. 2016, 19, 111-137. [CrossRef]

9. Collinson, D. Dichotomies, dialectics and dilemmas: New directions for critical leadership studies? Leadership 2014, 10, 36-55. [CrossRef]

10. Chreim, S. The (non)distribution of leadership roles: Considering leadership practices and configurations. Hum. Relat. 2015, 68, 517-543. [CrossRef]

11. Gronn, P. The view from inside leadership configurations. Hum. Relat. 2015, 68, 545-560. [CrossRef]

12. Crawford, M. Solo and distributed leadership: Definitions and dilemmas. Educ. Manag. Adm. Leadersh. 2012, 40, 610-620. [CrossRef]

13. Hairon, S.; Goh, J. Pursuing the elusive construct of distributed leadership: Is the search over? Educ. Manag. Adm. Leadersh. 2015, 43, 693-718. [CrossRef]

14. Konradt, U. Toward a theory of dispersed leadership in teams: Model, findings, and directions for future research. Leadership 2014, 10, 289-307. [CrossRef]

15. Oborn, E.; Barret, M.; Dawson, S. Distributed leadership in policy formulation: A socio-material perspective. Organ. Stud. 2013, 34, 253-276. [CrossRef]

16. Spillane, J.P.; Halverson, R.; Diamond, J. Towards a theory of leadership practice: A distributed perspective. J. Curric. Stud. 2004, 36, 3-34. [CrossRef] 
17. Currie, G.; Lockett, A.; Suhomlinova, O. The institutionalization of distributed leadership: A 'Catch-22' in English public services. Hum. Relat. 2009, 62, 1735-1761. [CrossRef]

18. Paredes-Scribner, J.; Sawyer, R.K.; Watson, S.T.; Myers, V.L. Teacher teams and distributed leadership: A study of group discourse and collaboration. Educ. Adm. Q. 2007, 43, 67-100. [CrossRef]

19. Bennett, N.; Wise, C.; Woods, P.; Harvey, J. Distributed Leadership: A Review of the Literature; National College of School Leadership: Nottingham, UK, 2003.

20. Gronn, P. Distributed leadership as a unit of analysis. Leadersh. Q. 2000, 13, 423-451. [CrossRef]

21. Gronn, P. Distributed properties: A new architecture for leadership. Educ. Manag. Adm. 2000, 28, 317-338. [CrossRef]

22. Gronn, P. Fit for purpose no more? Manag. Educ. 2016, 30, 168-172. [CrossRef]

23. Harris, A. Distributed leadership and school improvement: Leading or misleading? Educ. Manag. Adm. Leadersh. 2004, 32, 11-24. [CrossRef]

24. Harris, A. (Ed.) Distributed Leadership. Different Perspectives; Springer: Dordrecht, The Netherlands, 2009; ISBN 978-1-4020-9736-2.

25. Harris, A.; Spillane, J.P. Distributed leadership through the looking glass. Manag. Educ. 2008, 22, 31-34. [CrossRef]

26. Mayrowetz, D. Making sense of distributed leadership: Exploring the multiple usages of the concept in the field. Educ. Adm. Q. 2008, 44, 424-435. [CrossRef]

27. Spillane, J.; Healey, K.; Parise, L.; Kenney, A. A distributed perspective on learning leadership. In Leadership and Learning; Robertson, J., Timperley, H., Eds.; Sage: London, UK, 2011; pp. 159-168.

28. Gronn, P. The future of distributed leadership. J. Educ. Adm. 2008, 46, 141-158. [CrossRef]

29. Spillane, J. Distributed Leadership; Jossey-Bass: San Francisco, CA, USA, 2006.

30. Spillane, J.; Halverson, R. Distributed Leadership in Practice, 1st ed.; Teachers College Press: New York, NY, USA, 2007; ISBN 978-0787965389.

31. DeWitt, P. Using the visible learning research to influence collaborative leadership. Educ. Sci. 2018, 8, 219. [CrossRef]

32. Jones, S. Distributed leadership: A critical analysis. Leadership 2014, 10, 129-141. [CrossRef]

33. Lumby, J. Distributed leadership: The uses and abuses of power. Educ. Manag. Adm. Leadersh. 2013, 41, 581-597. [CrossRef]

34. Woods, P.A. Authority, power and distributed leadership. Manag. Educ. 2016, 30, 155-160. [CrossRef]

35. Barnett, K.; MacCormick, J. Leadership and team dynamics in senior executive leadership teams. Educ. Manag. Adm. Leadersh. 2012, 40, 653-671. [CrossRef]

36. Kelley, C.; Dikkers, S. Framing feedback for school improvement around distributed leadership. Educ. Adm. Q. 2016, 52, 392-422. [CrossRef]

37. Timperley, H. A distributed perspective on leadership and enhancing valued outcomes for students. J. Curric. Stud. 2008, 40, 821-833. [CrossRef]

38. Firestone, W.A.; Martínez, C. Districts, teacher leaders, and distributed leadership. Changing instructional practice. In Distributed Leadership according to the Evidence; Leithwood, M., Mascall, B., Strauss, T., Eds.; Routledge: Nueva York, NY, USA, 2009; pp. 61-86.

39. Alyami, R.; Floyd, A. Female school leaders' perceptions and experiences of decentralisation and distributed leadership in the tatweer system in Saudi Arabia. Educ. Sci. 2019, 9, 25. [CrossRef]

40. Bolden, R. Distributed leadership in organizations: A review of theory and research. Int. J. Manag. Rev. 2011, 13, 251-269. [CrossRef]

41. Bolden, R.; Ptrov, G.; Gosling, J. Distributed leadership in Higher Education: Rethoric and reality. Educ. Manag. Adm. Leadersh. 2009, 37, 257-277. [CrossRef]

42. Harris, A. The changing context of leadership: Research, theory and practice. In Effective Leadership for School Improvement; Harris, A., Day, C., Hadfield, M., Hopkins, D., Hargreaves, A., Chapman, C., Eds.; Routledge Falmer: New York, NY, USA, 2003; pp. 9-19.

43. Fung, A. Understanding the leadership qualities of a head of department coping with curriculum changes in a Hong Kong secondary School. Sch. Leadersh. Manag. 2010, 30, 367-386. [CrossRef]

44. García-Martínez, I. Coordinación pedagógica y liderazgo distribuido en los institutos de secundaria. Rev. Int. Didáctica Organ. Educ. 2016, 1, 21-34. 
45. Hulpia, H.; Devos, G.; Rosseel, Y.; Vlerick, P. Dimensions of distributed leadership and the impact on teachers' organizational commitment: A study in secondary education. J. Appl. Soc. Psychol. 2012, 42, 1745-1784. [CrossRef]

46. Moral, C.; Amores, F.J.; Ritacco, M. Liderazgo distribuido y capacidad de mejora en centros de educación secundaria. Estud. Sobre Educ. 2016, 30, 115-143.

47. Poultney, V. The role of the effective Subject Leader: Perspectives from practitioners in secondary schools. Br. Educ. Leadersh. Manag. Adm. Soc. 2012, 21, 8-14. [CrossRef]

48. Hallinger, P.; Heck, R.H. Leadership for learning: Does collaborative leadership make a difference in school improvement? Educ. Manag. Adm. Leadersh. 2010, 38, 654-678. [CrossRef]

49. Louis, K.; Leithwood, K.; Wahlstrom, K.; Anderson, S. Investigating the Links to Improved Student Learning: Final Report of Research Findings; Wallace Foundation: New York, NY, USA, 2010.

50. Ni, Y.; Yan, R.; Pounder, D. Collective leadership: principals' decision influence and the supportive or inhibiting decision influence of other stakeholders. Educ. Adm. Q. 2018, 54, 216-248. [CrossRef]

51. Raelin, J.A. What are you afraid of: Collective leadership and its learning implications. Manag. Learn. 2018, 49, 59-66. [CrossRef]

52. Woods, P.A. Democratic leadership: Drawing distinctions with distributed leadership. Int. J. Leadersh. Educ. 2004, 7, 3-26. [CrossRef]

53. Llamas, J.C.; Serrat, M.F. Is there a way out? A critical analysis of participation, leadership and management in Spanish schools. Int. J. Leadersh. Educ. 2002, 5, 303-322. [CrossRef]

54. European Union. School Autonomy in Europe Policies and Measures; Eurydice: Brussels, Belgium, 2008; ISBN 978-92-79-07522-3.

55. Spillane, J.P.; Zuberi, A. Designing and Piloting a leadership daily practice log using logs to study the practice of leadership. Educ. Adm. Q. 2009, 45, 375-423. [CrossRef]

56. Pitts, V.M.; Spillane, J.P. Using social network methods to study school leaders. Int. J. Res. Methods Educ. 2009, 32, 185-207. [CrossRef]

57. Denzin, N.K. Critical Qualitative Inquiry. Qual. Inq. 2017, 23, 8-16. [CrossRef]

58. Stake, R.E. The Art of Case Study Research; Morata: Madrid, Spain, 1995; ISBN 978-8471124227.

59. Wadham, H.; Warren, R.C. Telling organizational tales: The extended case method in practice. Organ. Res. Methods 2014, 17, 5-22. [CrossRef]

60. Czarniawska, B. Shadowing and Other Techniques for Doing Fieldwork in Modern Societies; Liber: Malmö, Sweden, 2007; ISBN 978-8763002158.

61. Krippendorff, K. Content Analysis: An Introduction to its Methodology; Sage: Thousand Oaks, CA, USA, 2004; ISBN 0-7619-1544-3.

62. Stake, R. Qualitative Research. Studying How Things Work; Guilford: New York, NY, USA, 2010; ISBN 978-1-60623-545-4.

63. Hargreaves, A.; Fullan, M. Capital Profesional; Morata: Madrid, Spain, 2014; ISBN 9788471127976.

64. Spillane, J.P.; Camburn, E.M.; Pareja, A.S. Taking a distributed perspective to the school principal's workday. Leadersh. Policy Sch. 2007, 6, 103-125. [CrossRef]

65. Camburn, E.; Rowan, B.; Taylor, J.E. Distributed leadership in schools: The case of elementary schools adopting comprehensive school reform models. Educ. Eval. Policy Anal. 2003, 25, 347-373. [CrossRef]

66. Leithwood, K.; Mascall, B.; Strauss, T.; Sacks, R.; Memon, N.; Yashkina, A. Distributing leadership to make schools smarter: Taking the ego out of the system. Leadersh. Policy Sch. 2007, 6, 37-67. [CrossRef]

67. Hargreaves, A.; Fink, D. El Liderazgo Sostenible. Siete Principios Para el Liderazgo en Centros Educativos Innovadores; Morata: Madrid, Spain, 2008; ISBN 9788471127662.

68. Harris, A. Distributed School Leadership; Routledge: New York, NY, USA, 2008; ISBN 978-0415419581.

69. Harris, A. Liderazgo y Desarrollo de Capacidades en la Escuela; Fundación Chile, Centro de Innovación en Educación: Santiago, Chile, 2012; ISBN 9789568200275.

70. Harris, A.; Jones, M. Professional Learning Communities in Action; Leannta Publishing: London, UK, 2011; ISBN 9780956376015.

71. Slater, L. Pathways to building leadership capacity. Educ. Manag. Adm. Leadersh. 2008, 36, 55-69. [CrossRef]

72. Göksoy, S. Distributed leadership in educational institutions. J. Educ. Train. Stud. 2015, 3, 110-118. [CrossRef]

73. Diamond, J.B.; Spillane, J.P. School leadership and management from a distributed perspective: A 2016 retrospective and prospective. Manag. Educ. 2016, 30, 147-154. [CrossRef] 
74. Klein, M. Democratizing Leadership: Counter-Hegemonic Democracy in Organizations, Institutions and Communities; Information Age Publishing Inc.: Charlotte, NC, USA, 2016; ISBN 978-1681233338.

75. Holmes, J.; Stubbe, M. Power and Politeness in the Workplace: A Sociolinguistic Analysis of Talk at Work; Logman: London, UK, 2003; ISBN 978-1138809055.

76. Choi, S.; Schnurr, S. Enacting and negotiating power relations through teasing in distributed leadership constellations. Pragmat. Soc. 2016, 7, 482-502. [CrossRef]

77. Woods, P.A. Within you and without you: Leading towards democratic communities. Manag. Educ. 2007, 21, 38-43. [CrossRef]

78. Capper, C. Empowering Leadership. Similarities and contradictions in critical, poststructural and feminist, otherist perspectives. In Paper Present at Annual Meeting of AERA; AERA: San Francisco, CA, USA, 1995.

79. Woods, P.A.; Gronn, P. Nurturing democracy: The contribution of distributed leadership to a democratic organizational landscape. Educ. Manag. Adm. Leadersh. 2009, 37, 430-451. [CrossRef]

80. Hatcher, R. The distribution of leadership and power in schools. Br. J. Sociol. Educ. 2005, 26, $253-267$. [CrossRef]

81. Maxcy, B.D.; Nguyen, T.S.S. The politics of distributing leadership: Reconsidering leadership in two Texas elementary schools. Educ. Policy 2006, 20, 163-196. [CrossRef]

82. Leithwood, K.; Mascall, B.; Strauss, T. Distributed Leadership according to the Evidence; Routledge: New York, NY, USA, 2009; ISBN 9780203868539.

83. Spillane, J.; Diamond, J.B. Distributed Leadership in Practice, illustrated ed.; Teachers College Press: New York, NY, USA, 2007; ISBN 978-0807748060.

84. Bush, T. Prescribing distributed leadership: Is this a contradiction? Educ. Manag. Adm. Leadersh. 2018, 26, 535-537. [CrossRef]

(C) 2020 by the authors. Licensee MDPI, Basel, Switzerland. This article is an open access article distributed under the terms and conditions of the Creative Commons Attribution (CC BY) license (http://creativecommons.org/licenses/by/4.0/). 